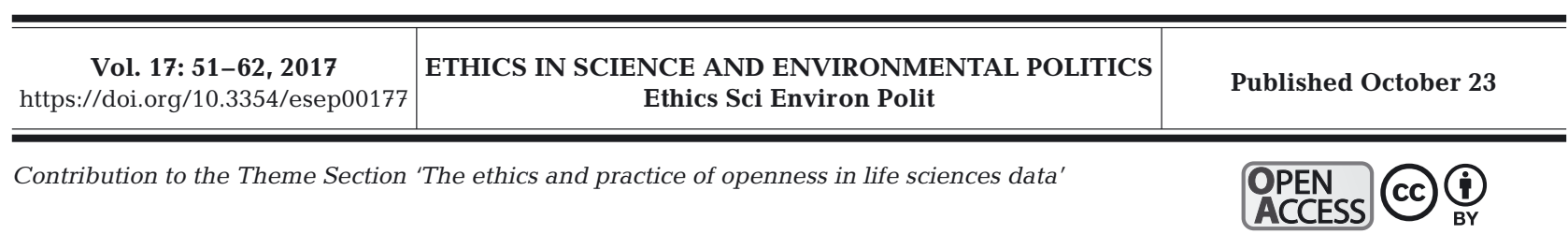

\title{
The maladies of enlightenment science
}

\author{
Tim Wyatt* \\ Barrio A Tomada, Borreiros, Gondomar, 36378 Pontevedra, Spain
}

\begin{abstract}
Some of the amalgam of activities which comprise traditional science ('real' science) has fragmented into new modes under pressure from internal and external factors. The adoption of the internet and the World Wide Web (which have created cyberscience and are internal factors) can be equated with the introduction of the microscope and other instruments and procedures, though they have revolutionized the whole of science rather than some of its branches. External factors discussed here include post-modernism, neoliberalism, and McDonaldization. In post-modern science, the traditional model has become burdened by social and political interests, and concerns for practical problems in which scientific expertise can assist decision making; however scientific knowledge in itself is not a priority. Neoliberal guile has parasitized science as it has so much else in search of profit, and has seriously damaged its host. There are also degraded or pathological activities, 'McScience', in which the pursuit of knowledge has been corrupted by an excess of bureaucratic control and over-emphasis on personal rankings. The ethos which guides traditional science has been warped by these various outside interests, secrecy is rewarded, and practices once considered dishonest are prospering.
\end{abstract}

KEY WORDS: Enlightenment - Traditional science - Postmodernism • McDonaldization · Neoliberalism · Cyberscience

\section{TRADITIONAL SCIENCE}

Science started to acquire its modern sense (as 'natural philosophy') during the Scientific Revolution, from Copernicus to Newton and the Age of Enlightenment, as it gradually freed itself from the shackles of theology and absolutism, from a thousand years of stasis and obscurantism (Russo 1996). Under the influence of Descartes, Leibniz, and others, faith and dogma gave way to rationalism. 'Gradually, theoreticians behind the movement that had begun as a grand attempt to merge God and syllogisms realized that logic did not require the link to the divine' (Schlain 1998). When the Royal Society of London was founded in 1660, it tried to protect itself from intellectual fallacies, from the 'four kinds of illusions which block men's minds'. These illusions, listed by Francis Bacon in his Novum Organum Scientiarum, were (1) the idola tribus (idols of the tribe), perceptual errors due to the limitations of the senses; (2) the

\footnotetext{
*Corresponding author: timwyatt1937@gmail.com
}

idola specus (idols of the cave), personal prejudices; (3) the idola fori (idols of the marketplace) caused by shared language and commerce; and (4) idola theatri (idols of the theatre), i.e. systems of philosophy and proof-whence came the Royal Society's motto 'Nullius in verba' (which means do not take anybody's word for it), and the exclusion of discussions concerning politics and religion, impediments to clear thought, from its conduct.

From then until quite recently, science was almost universally regarded as a system which formulates laws to describe information and turn it into knowledge, the systematic study of nature by methodical processes of observation, experiment, measurement and inference which generate that information, and tests of the laws. These procedures are collectively called the scientific method. 'It is the matter-of-fact as against the romantic, the objective as against the subjective, the empirical, the unprejudiced, the ad hoc as against the a priori' (Waddington 1948, p. 61).

(C) The author 2017. Open Access under Creative Commons by Attribution Licence. Use, distribution and reproduction are unrestricted. Authors and original publication must be credited. 
Not all branches of science fit this model. In the classical procedures of physics, single parameters are isolated and manipulated whilst others are held constant; control experiments can be set up, and replication is possible. Historical sciences such as cosmology, geology, palaeontology, or evolutionary biology cannot deploy these procedures. Nevertheless, we can recognize a group of academic disciplines that share a common identity.

Normally, hypothesis comes first, and decides what will be observed; the dialectic between speculation (not necessarily mere as in the pejorative tense) and skepticism is what leads to good science (Medawar 1967). Science, then, is a search for patterns. Its laws, or theoretical truths, when they are discovered, are independent of any practical applications they may subsequently be found to have-a notion unfamiliar in some quarters. There is much in science without any discernible economic value; do we need to know about the Ediacaran fauna or the Permian extinction, whales' songs or spiders' dances? The answer is yes in each case, not for economic reasons, but because it is fascinating, gripping, and above all fun. For many scientists, understanding is more important than technical applications, and for those who play in the arena of pure mind, science may be a personal search for karma. But for most, social rewards are sought.

In the kind of science just outlined, there is not necessarily a direct flow from science to technology and consumer products. Even though much technology today is applied science and the 2 form a conceptual continuum, certain aspects of science can be so pure or esoteric, even though their pursuit depends on technology, that their value must be sought elsewhere. Much technology too is independent of science; there is no lockstep relationship between the 2 . Did the invention of the sewing needle, say, or the screwdriver, of barbed wire or Teflon, depend on science? Practical steam engines preceded the science of thermodynamics by nearly a century. Equally, most discoveries depend on technology. There is no stellar chemistry without spectroscopy, nor cell theory without microscopy. In the present context, science has been demonstrably open in some ways, at least in times of peace and when free from bureaucratic meddling, while technology has not. But the secrecy of inventors is condoned, and Galileo played both cards.

This is not to say that the scientific tradition has a monolithic unity; far from it, it is rather an amalgam. Scientists include 'collectors, classifiers, and compulsive tidiers-up; many are detectives by temperament and many are explorers, some are artists and other artisans. There are poet-scientists and philosopherscientists and even a few mystics' (Medawar 1986); but most to varying degrees subscribed to the professional ethos for which Ziman (1994) coined the mnemonic CUDOS (communalism, universalism, disinterestedness, originality, skepticism), adding originality to Merton's (1942) 4 standards of the scientific ethos. In this ideal world, good science is produced by ethical scientists; later, we see that the good and the ethical have become disconnected (Nosek et al. 2012, Smaldino \& McElreath 2016).

It is true that 'Scientific life would not be human if it were not permeated with folly, incompetence, selfinterest, moral myopia, bureaucracy, anarchy and so on' (Ziman 2000, p. 5), all sources of bias and error. But the drive for objectivity in science is a feature of the community, however partisan its individual members might be, and has in principle been determined by openness based on collegiality and trust. In the well-known allegory in the Republic, Plato leads us from the obscurity of the cave where individual opinions rule (idola specus) to the outer sunshine, the realm of episteme, knowledge, where claims must be justified in public. Knowledge obtained by science according to this tradition becomes part of the intellectual or cultural commons, what Sprat (1667) called the 'publick Treasure', freely available to all.

Scientific exploration of nature is in principle rational (Popper 1959); but research is driven by passion as well as reason, and rivalry, ambition and prejudice are significant inputs. There are those who crave recognition and may forego academic discipline in pursuit of the rewards of fame and influence. It is against the background of this mental potpourri that the dilemma of scientific openness and secrecy is mediated. Thus, traditional science is embedded in a social context, only one function of which is to strive for objectivity. Scientists themselves are expected to make results public so that their peers can test their reliability. Ideas and results are shared, honed, distilled, embellished, rejected, and often ignored. All such evaluation procedures are institutionalized to varying degrees, most clearly in the editorial/peer review system. In making their work public, researchers can establish priority and gain professional recognition - parts of the reward system. So the essence of scientific communication comprises published accounts of research such that, potentially, the work can be repeated with similar results. This requires that experimental methods and analytical tools be described in sufficient detail for such independent tests to be carried out. For the historical sciences and 
for purely theoretical or speculative advances, comparable transparency is required. Good science can withstand detailed scrutiny, and does not hide its procedures.

This simple ethos has long guided scientific communication, although human foibles add many colors to it. Galileo Galilei, one of the founders of modern science, was a master of information control: his Sidereus Nuncius (1610) in which he reported the existence of 4 of Jupiter's moons, was 'a balancing act between communication and secrecy, between the desire to have his discoveries accepted and that of slowing down potential replicators so that they would not become his competitors' (Biagioli 2006, p. 16). Galileo withheld the technical details of his telescope which 'allowed him to develop a monopoly on observational astronomy' (Biagioli 2006, p. 125). Priority disputes have often been bitter, contestants' behavior vitriolic. There were flagrant clashes between Robert Hooke and Christiaan Huygens (about the hairspring), between Evangelista Toricelli and Blaise Pascal (mercury barometer), between Ronald Ross and Giovanni Battista Grassi (life cycle of malarial parasite), and especially between the unrelentingly vindictive Isaac Newton and Gottfried Leibniz (the calculus), a dispute which outlasted both of them. The lyrics of Tom Lehrer's Lobachevsky spring to mind. In more recent times, James Watson (1968), codiscoverer of the structure of DNA, thought secrecy should be encouraged so as to win 'the race' and reap the honors. Does temporary secrecy pass as openness?

Science today seems to almost always be under pressure from other constituencies, each with its distinct ethos, perhaps more so than formerly. Much of this pressure is based on financial instruments and bank credits, and the ambitions of John Stuart Mill's Homo economicus. This pressure has increased in recent decades as neoliberal ideas have been implemented. Scientific knowledge and the data which underpins it are becoming commodified, and the traditional openness of the scientific ethos can impinge on market values. In business, secrecy and reticence are elementary instincts whenever something has the smell of potential profit. 'The tongue hath no force when gold speaketh' wrote Stefano Guazzo ${ }^{1}$. There is thus a conflict about how open the communication process should be, and whether scientific data and their interpretations should be shared freely with third parties rather than being traded as commodities. Neoliberalism, that is 'faith-based econom-

${ }^{1}$ Guazzo S (1581) The ciuile conuersation. George Pettie's translation. See Guazzo (1925) ics masquerading as science' (Gray 2009), destroys the science it wishes to emulate, just as it destroys other social institutions (Gray 2009).

\section{NEW SCIENCES, NEW ETHEA}

The preceding paragraphs outlined some aspects of the dominant tradition of how science worked for some centuries and how much of it still works today. Ziman (2000) called this 'real science'. However in recent decades, this tradition has been subjected to destructive pressures from several directions. Some scientific problems have become much more demanding of capital investment and thus more vulnerable to political and industrial tampering. In the spirit of universal Darwinism, one might say that selection is acting on variations in the original tradition (its functional traits), creating new species of science. Here, the analogy refers to the social procedures of science, and is therefore distinct from the 'evolutionary epistemology' of Kuhn (1962) or Dawkins (1976) in which it is the content that evolves: but the procedures cannot change without having an impact on the resulting knowledge, and on its ideological claims.

Some of these new species are added to the many pseudosciences, Medawar's (1977) Unnatural science (Chaucer's unscience in Boece) which have long accompanied traditional science, astrology, augury, various sorts of medical quackery (Starr 1982), as well as more recent aspirants. A short list includes Lysenkoism (which rejected Mendelian inheritance), psychoanalysis (Popper 1959, Gray 2014, Chapter 2), intelligent design (Dawkins 1996, Pigliucci 2002), homeopathy (Ernst 2010), IQ testing (Gould 1981), parapsychology, psychokinesis; see Gardner (1952) for more. Finally, somewhere between science and pseudoscience, we can mention weird science (Hollings 2008), a rag bag of topics, some pursued in secret by government agencies, which ranged (in the 1950s at least) from a search for 'truth drugs' to dianetics and flying saucers.

Some new species now discerned as distinct from traditional science have been given names. We can list, in no particular order, post-modern science (Polanyi 1974, Feyerabend 1988), post-normal science (Funtowicz \& Ravetz 1993, Ravetz 1996), mode-2 science (Gibbons et al. 1994), cyberscience (Wouters 1996, Nentwich 2003) and science 2.0 (Shneiderman 2008), neoliberal science (Lave et al. 2010), and junk science (Agin 2007). Horton's (2004a) McScience includes some of them. Krimsky (2003) describes cor- 
rupted science as dishonest, lacking in integrity and objectivity, and cut off from its ethical roots, characteristics blamed partly on generous corporate funding (see below). Goldacre's (2008) 'bad' science includes McScience and other illegitimate offspring of real science, and exposes the often uninformed rhetoric and propaganda which accompanies it.

This list is not exhaustive. Ravetz (1996, p. xiv) also offers us shoddy science, entrepreneurial science, reckless science, and dirty science, the 'four horsemen of the scientific apocalypse'. The fraud and misconduct components which characterize some of these are sometimes due to commercial pressures, but obviously scientists themselves are often guilty, driven by ambition and the search for laurels. We read too of settled science, consensus science, and other oxymorons. There are neither incontrovertible nor inconvenient truths in science, though we do sometimes meet convenient untruths. Some of these new species are eroding the academic space occupied by traditional science.

\section{POST-MODERN SCIENCE}

Proponents of post-modern science argue that all knowledge is relative to the culture in which it is embedded and the frailty of language, that true objectivity cannot exist. Post-modernists claim Friedrich Nietzsche as their own - 'Words are but symbols for the relations of things to one another and to us; nowhere do they touch upon absolute truth' (Nietzsche 1962, p. 83). It is in one sense an attempt to deconstruct the 'Enlightenment project' (Kuntz 2012) with its commitment to reason, thus a kind of intellectual abuse or anti-science. In its extreme form, social constructivism stands Francis Bacon on his head, and maintains, for example, that the 'natural world has but a small or non-existent role in the construction of scientific knowledge' (Collins \& Pinch 1993); this is obviously a hostile and nihilistic view, hardly an advance on pre-Socratic solipsism. Postmodernist arguments of this kind were targets in the so called 'science wars' of the 1990s (Gross et al. 1996). Less extreme arguments from neo-Marxists and others maintain that scientific ideas are (and historically have been) determined by economic and social interests; there is no doubt that study topics are influenced by such interests, but this does not mean objectivity is necessarily impugned.

Constructivists have reactivated the idols in the Baconian theatre, but this has not had any impact on the way traditional science is done. There is no con- flict between constructivism and science at the operational level. The scholarly accomplishments of constructivism need free access to information from all inputs to remain robust.

\section{POST-NORMAL SCIENCE}

Post-normal science is a response to the realization that Adam Smith's 'invisible hand' metaphor has proved delusional, that unconstrained individual greed and slash-and-burn capitalism cannot make rational decisions about the management and conservation of natural resources, nor can these decisions always await the results of hard science. Science itself does not 'possess an invisible hand mechanism through which the naked self-interest of individuals necessarily brings about a collectively optimal result' (Smaldino \& McElreath 2016, p. 5). Post-normal science is a hybrid between ecology and economics, between epistemology and governance, stresses that evaluations cannot be reduced to onedimensional standards, and that the quality of policy decisions is more important than scientific truth. It is therefore not really science at all, but scientific information comprises one node in complex decision making processes.

\section{SCIENCE 2.0}

Shneiderman's $(2008,2016)$ science 2.0 is a research manifesto and has much in common with post-normal science. It advocates a multidisciplinary programme of applied 'science, engineering, and design' to tackle problems like disaster response systems or environmental sustainability based on collaboration using computer tools and the internet. Since science 2.0 forbids a purely reductionist approach, the claim that actionable problems are inaccessible to traditional science is sound enough: its 'immense problems' are then only remotely scientific problems. To become accessible they need to be broken into smaller pieces. To deal with such problems, Shneiderman outlines 5 strategies, one of which is indeed classical reductionist science, useful to tackle the smaller pieces! We can agree that solutions to complex problems demand multidisciplinary approaches. It is not obvious how rebranding the search for such solutions as science 2.0 helps.

New products and better community services may result from science 2.0 , but scientific truth is not a priority. Shneiderman is amongst the many who believe 
we need to accelerate progress, as though innovation is a panacea for the greed run riot of our neoliberal times. Collaborative projects which call on expertise from diverse disciplines have an important potential reward, to reduce what is filtered from the perceptions of individual collaborators, of scientists as well as other players. However, from the scientific perspective there is a downside. Should lay opinions or the values of stakeholders play roles in scientific decisions? The answer is no. This is simply appeasement and intellectual cowardice; it both sidelines the science and dilutes evidence with opinion.

\section{NEOLIBERAL SCIENCE}

There are powerful voices demanding that scientific procedures be politicized and the products privatized and commercialized. These voices emanate from the blinkered economic doctrine called neoliberalism. While constructivists pry into the accepted rectitudes of science, a purely academic exercise, economic pressure from the neoliberal Right is driving the practice of science into new molds. Idealism is under pressure from ideology; this has been labeled 'mode 2' science by Gibbons et al. (1994), neoliberal science by others.

Much present-day scientific research activity is now conducted in the spirit of or in apparent imitation of methods to improve industrial processes (pioneered by Frederick Winslow Taylor). Control of much that is done in many laboratories has been transferred from scientists and their technical colleagues to line managers, and research, data analysis, report writing, etc., are constrained by Gannt charts or their modern equivalents, fashionable charades which often assume an air of spurious certainty. Even quite small collaborative projects are mission oriented and have coordinators and associated contractors and sub-contractors who prepare task reports and technical progress reports and lists of deliverables (= quantifiable goods or services); there is dialogue and networking and there are milestones and players and stakeholders. These are the sound bites of politics and trade, not traditional science. All this project management is coercive at the microlevel of individuals, social engineering at the macrolevel. Informal procedures, once characteristic of small groups of collaborators, are replaced by managerial straightjackets; a pointer moves along a scale from open to totalitarian. It is not the quality of science which is at stake but abstract standards derived from outside science. Scientific issues are trans- formed into political ones, and knowledge is treated as a product, commodified, and subjected like consumer goods to market criteria.

Much research now begins with such proposal writing, a minor art form in which the supplicant might make 'inferences about an unknown territory from an unfaithful map' (Eco 1994, p. 98), while simultaneously attempting to persuade patrons that the expected results will be innovative and with high potential impact. It is as though results are already known before a study has been started. Supplicants are well aware that scientific discoveries are not normally produced by logical arguments, but they must persuade patrons otherwise; beyond the subterfuge, evaluation can effect changes, presumably unintended, in research methods and objectives, as well as introduce surveillance. In addition, administrative (i.e. artificial) time scales are imposed on research activities, whatever natural rhythms they may have, and there is no space for blue-sky research. The implication is that research is a process of production (per time unit), presumably measured with bibliometric indices, or in some cases by numbers of patents. This kind of evaluation goes far beyond the need to provide accountability for public funding, and tends to be coercive and normalizing so that, paradoxically, it can inhibit the innovation which scores high points! 'The path of creativity is strewn with the bones of those consumed by the vultures of mediocrity, accountability, and responsibility' (Loehle 1990, p. 129). Outside evaluation also destroys the collegial spirit that once held sway, and is undemocratic.

The peer-to-peer openness and trust referred to earlier has not been replaced (yet?), but is losing some of its former importance as newer systems of evaluation are imposed. These are linked to social or political values defined by evaluators who often have no expertise in science or any other kind of research, and who make use of low-dimensional numerical measures (cf. intelligence quotients or the GNP) to quantify categorical variables. Some evaluation protocols have little to say about the quality of the science assessed. Thomasina Coverly in Tom Stoppard's play Arcadia finds 'a truly wonderful method whereby all the forms of nature must give up their numerical secrets and draw themselves through numbers alone'. It does not work in the real world.

Each individual scientist and evaluator has his or her own self-interest; individuals in both groups wish to promote their own power, the former with science and ambition, the latter with power and ambition. Innovative thinking cannot be imposed by budgets or 
other means (Medawar 1967). 'Indeed, in our reckoning, an aspiration of excellence seems as much amorphous as futile; a truly Sisyphean pursuit' (Watermeyer \& Olssen 2016, p. 206).

A unique feature of neoliberal biomedical science is the way work is subcontracted. For example, clinical trials can be put out to tender, and contracts agreed with commercial research organizations. The results of such trials are then compiled and analysed by ghostwriters working for companies that mimic scientific papers; with the help of a little baksheesh from the pharmaceutical industry, academics of standing (thought leaders) are next identified who allow their names to be attached as honorary authors (Horton 2004b, McHenry 2010). These services are not cheap; a single manuscript can cost as much as the annual salary of a scientist. A decade ago, it was reported that more than $50 \%$ of articles about clinical trials published in The Lancet, the New England Journal of Medicine and the Journal of the American Medical Association are ghostwritten (Anon 2005); medical journals 'have evolved into information laundering operations for the pharmaceutical industry' (Horton 2004b).

Corporate interests can be further improved by inventing new diseases: 'the pharmaceutical industry is working behind the scenes to help define and design the latest disorders and dysfunctions in order to create and expand markets for their newest medicines' write Moynihan \& Henry (2006); 'social anxiety disorder', 'pediatric bipolar disorder' and 'premenstrual dysphoric disorder' are a few examples of such duplicity. Invention is the mother of necessity so to speak. Authors and editors critical of the pseudoscience and others who expose the corruption can expect to face litigation. Full and unrestricted access to the raw data is not encouraged, and confidentiality agreements with sponsors are the norm. Corporate sponsorship ensures that stock values over-ride medical ethics (Horton 2004b).

Neoliberal pressure on scientific communication has affected the shifting balance between cooperation and competition, which moves the cursor along a vector from openness to secrecy. Use of the internet, development of electronic data bases, and advances in the speed and power of computing have added new ingredients to the desire to protect priority, credit, and intellectual property rights (Resnik 2006). Even before neoliberalism became mainstream, market forces distorted the open nature of traditional science, and indeed science itself. Hobbes' (1668, p. 25) admonition 'against the lucrative vices of men of trade' falls on deaf ears. The results so far as re- viewed by Lave et al. (2010) are 'narrowing of research agendas to focus on the needs of commercial actors', 'fortification of intellectual property in an attempt to commercialize knowledge, impeding the production and dissemination of science', meaningless openness, and changes in 'the methods, organization, and content of science'.

Public research funding, once disbursed in a fiduciary capacity, now like corporate funding often seeks results with market potential, and socio-economic expectations move the cursor in the direction of secrecy. Worse yet, we are witness to 'the transmogrification of the university from free creative space to corporate [and government] panopticon' (Watermeyer \& Olssen 2016, p. 203). So 'the exploitation of intellectual property challenges the ideal of scientific knowledge as a public good. If intellectual property is valuable, it cannot be given away freely by open publication in peer-reviewed journals, or at scientific conferences open to all. However, the quality of science is largely determined by its exposure to refutation and counter-argument. This process becomes much more difficult if the circulation of research findings is restricted' (Nowotny et al. 2003, p. 183).

Ignorance and misunderstanding, like knowledge, are social constructions, used by scientists to obtain funding, and by commercial and political interests (Smithson 1989). Stocking \& Holstein (2009) provide a detailed case history concerning industrial pig production in North Carolina. Manufactured ignorance can be purposefully blended with the genuinely unknown and afforded a false legitimacy in debates. Even the genuinely unknown, a product of epistemic blind spots, can be exploited. Rachel Carson's (1962) exposé of the impact of pesticides is classic. Proctor (1995) details how government funding of cancer research fostered ignorance with respect to its environmental and industrial causes. The current debate about the problem of colony collapse disorder in bees is following the same pattern. Market interests often employ expressions like 'sound science', 'the science is settled', or alternatively, 'there is no conclusive scientific evidence' to create ambiguities and manipulate public perceptions.

We see that the ethical codes and canons of traditional science have been partially abandoned, and that this has led to a splintering or disintegration of at least one component of the enlightenment programme. There is no such animal as 'settled science'. The consensus can be wrong (or fibbing!); science deals in probabilities, not certainties. 'Para-journalism' and 'infotainment' spread these dishonest messages. 'The class which has the means of material 
production at its disposal, has control at the same time over the means of mental production, ...' (Marx 1846). Freedom to differ from majority opinion, and to resist pressure to conform, is essential for scientific progress, so that legislation to silence nonconformist views is counterproductive. History often shows that unorthodox science can come in from the cold. Alfred Wegener's hypothesis of continental drift, long mocked, is an example (Oreskes 1999); its descendent, plate tectonics, is still not necessarily settled (Storetvedt 1997).

\section{McSCIENCE}

Horton's McScience recalls Ritzer's (1998, 2011) McDonaldization (itself something of a franchise, with 7 editions in $15 \mathrm{yr}$ !), a sociological model which focuses on 4 features of the fast food industry; production (quantity) must aim to be efficient (minimize the time to do things), quantifiable (quantity is more important than quality), predictable (work tasks are repetitive, routine), and controllable (employees are standardized). Everything is reduced to numbers, and the product is cheap, easy to make, fast (obviously!), but short on authenticity. The model could be an overture to a repackaged and sanitized science, a kindergarten science. Some science is already a manufacturing enterprise, churning out papers which maintain production rates, but at the cost of quality. The fragmentation of factory work which Frederick Taylor counseled is now met in laboratories, many now staffed by a generation of highly trained people with McJobs, amassing data for McThinkers who in turn are calculating how thinly the salami can be sliced, and dreaming of boosting their McImpact factors.

There are lobbies in science as well as in politics, and in some industries there have been (and are) strategies to provide scientific validity for conclusions which have been decided in advance, as well as obfuscate or denigrate embarrassing data. Michaels (2008) gives a detailed account of such perversions from a variety of industries (pharmaceuticals, tobacco, asbestos, pesticides, dyes, ...). Recently, collusion between the sugar industry and Harvard academics in the 1960s and 1970s has come to light; this deflected attention from the link between sucrose consumption and coronary heart disease, and pointed instead at fats and cholesterol (Bes-Rastrollo et al. 2013, Kearns et al. 2016). Funding by the Sugar Research Foundation was concealed. These practices are pure McScience.

\section{CYBERSCIENCE}

Cyberscience (also e-science) refers to science carried out in cyberspace, to take advantage of networked computers and state-of-the-art information and communication applications (grid technology) and create virtual research environments. It goes beyond the use of individual computers as tools for storing and processing information, provides collaborators in geographically dispersed scientific projects the ability to archive and access very large data collections, and enables them to manipulate, model, and visualize with almost unlimited computing power. Cyberspace offers new opportunities for research, just as the telescope and the microscope have in the past (and of course still do). The tools of cyberspace provide new means that will ease the extraction of information from data, and of knowledge from information' (Hey 2006, p. vii).

According to Douglas Engelbart, inventor of the mouse, 'the digital revolution is far more significant than the invention of writing or even of printing' (quoted by Bauerlein 2009). It seems probable that Marshall McLuhan would have agreed had he lived to witness it. Twenty years ago as the digital world was taking shape, Jon Katz (1997) wrote that the generation to whom it had already become second nature 'take no one's word for anything'! The motto of the Royal Society has found a home in a new constituency. Katz also wrote: 'The Internet is still a wild frontier. The hackers and geeks who founded and shaped it believed that there should be no obstacles between people and information, and there are still vibrant, almost outlaw communities that enforce this notion: cypherpunks who act as technoanarchists, flamers who challenge punditry, hackers who breech the barriers constantly being thrown up by government and business.' Twenty years later such barriers continue to be erected - and torn down or bypassed.

Research areas ranging from genomics and proteomics to particle physics and meteorology are now heavily dependent on world-wide online databases and the tools to exploit them. Cyberscience is then a direct descendant of traditional science, undiluted by social and political inputs, and so distinct from postmodern science and science 2.0.

The internet may in the long run have a more profound impact on science than neoliberalism. The virtues of the internet as a tool for cyberscience are intermingled with its character as a consumer habitat, inimical to sustained thought. Combined with interruptions by e-mail, text messages and telephone calls, the pings and beeps of the digital environment, 
performance is disrupted, error rates increased, and attention replaced by distraction (Jackson 2008). This frenetic activity leaves little time for thought. The fragmentation of the technical part of research is matched by intellectual wounds. Screen time 'superpowers [young adults] social impulses, but it blocks intellectual gains' (Bauerlein 2009), and the transition from scholarly work to infotainment is only a mouse click away; 'the screen becomes not a vein of truth but a mirror of desire' (Bauerlein 2009), and eliteracy is replaced by illiteracy. Simultaneously, synergy between the internet and neoliberalism offers an open road to the malignant narcissism Eric Fromm wrote about in The Heart of Man (Fromm 1964); there is positive feedback between the psychological gratification of rising impact factors and the severity of the condition.

\section{OPENNESS}

A rather natural proprietary attitude to data has probably always accompanied the traditional ethos of science and set a limit on full openness. The free software movement, online mechanisms for scientific collaboration, and the Creative Commons project, which aims to regulate downstream use of intellectual property rights, partially free culture from the grip of corporate control and provide new models to avoid the open-closed impasse. Mayo Fuster Morell (2015), Lawrence Lessig (2004) and others are promoting openness in the digital world. These trends are 'becoming the equivalent of the socialist movement in the industrial age' (Bauwens 2005). Privatization and top-down control of information flows counter such projects, and capitalism sometimes dominates the relationship; but signs of a more balanced symbiosis are emerging.

The interface between transparency and secrecy has complex topography. Openness provides information to listeners and readers as well as peers, but the information transmitted can be filtered and its timing controlled to serve personal, institutional, or corporate needs, to ensure priority, or to feed motives related to patronage. Knowledge itself is power (ipsa scientia potestas est), wrote Francis Bacon in his Meditationes Sacrae (1597). As in a fitness landscape, movements towards open peaks or secret valleys can be driven by a variety of competing interests as mentioned at various points in the preceding pages. These range from the idealistic openness of the traditional ethos (peaks) to the secrecy which surrounds the inventions and innova- tions of individuals, corporations, or political and military interests (valleys). Between these extremes (on the slopes) lie the reticence of scientists who wish to assure priority and recognition for themselves or their colleagues, the exposure necessary for patent claims, the demands of society to be informed. Movements through this landscape are regulated by individual ethics, by contractual agreements of different kinds, by economic necessities, and by laws, but also by plagiarism, industrial and military espionage, by hacking, and by permutations of them. Each of these components of the landscape also has its time constants, and all of them have varied in importance through history (Long 2001). There are no simple tracks between the open peaks and the secret valleys. Like a categorical variable, the landscape of openness and secrecy resists quantification. Neither extreme can be reduced meaningfully to a single integer.

Not only have individuals succumbed to the new norms, but large sections of Academe too. Tuchman (2009) maintains that the traditional model for higher education has been abandoned-decisions formerly entrusted democratically to faculty members are now made by administrators, and agreements formerly guided by the common good are now replaced by edicts of an audit culture, coercion again. Universities no longer 'lead the minds of students to grasp truth; to grapple with intellectual possibilities; to appreciate the best in art, music and other forms of culture; and to work towards both enlightened politics and public service' (Tuchman 2009, p. 41). Many universities now give priority to their bottom lines. 'Each infringement on its [the university's] unwritten contract with society to avoid secrecy whenever possible and maintain its independence from government or corporate pressure weakens its integrity' (Klein 2000).

This article began with Francis Bacon's 4 idols. Ernst Gombrich (1979) wrote of 4 more idols in the context of the humanities, but applicable to some patterns of practice in science. His idola quantitatis expresses the belief that numeration is intrinsically praiseworthy, that a mathematical treatment of a theme is the ultimate in reductionism, or at least that it adds an air of necessary rigour. This is methodological naiveté. Intelligence quotients (Gould 1981) and impact factors are examples of the disease (Ramanathan 2002), as are the one-dimensional standards denounced by post-normal science. Idola novitatis refers to a cult of feigned originality of research, and idola temporis to the cult of the new as the focal point of interest. For example, 'it appears that the 
innovation rate has been skyrocketing. Or claims at innovation, at any rate. In the years between 1974 and 2014, the frequency of the words 'innovative', 'groundbreaking' and 'novel' in PubMed abstracts increased by $2500 \%$ or more' (Smaldino \& McElreath 2016 , p. 3). These are some of the words used to construct the assertive titles mentioned below. The protective and possessive instincts, the myopia of disciplinary boundaries and their jealous control, belong in the shrine of idola academica; the free flow of information and ideas is congealed or frozen by the devotees.

\section{DISCUSSION}

Democracy is a social system based on formal equality of rights and privileges, and in its European mid-20th century manifestation went hand in hand with collective rights to social protection and the redistribution of productivity. In contrast, corporatism seeks to reserve those benefits for a particular caste. These are the 'sacred' and 'satanic' (to twist Carey's Manichean world view) protagonists of modern western society, an unequal symbiosis verging on parasitism. Control of the flow of information, an essential ingredient of complex social systems, is a major factor giving an advantage to corporatism. Corporate propaganda, a means to protect itself from democratic demands (Carey 1997), is part of this control, and scientific data and scientific knowledge generally are both used and misused in pursuit of corporate interests, as indicated earlier.

The currently fashionable satanic neoliberalism is busily dismantling the Keynesian welfare state and replacing it, impervious to social and environmental losses. Freedom is redefined as economic freedom. Under the influence of pure market values, the former openness of science has mutated with the introduction of new concepts of intellectual property, and as resources formerly shared freely are privatized, the production and dissemination of science is retarded. Mirowski (2011) claims that these trends have qualitatively degraded the resulting scientific knowledge. Ongoing challenges to genetic engineering and gene patents, to attempts to own traditional medicinal plants, and other conflicts between privatization and the commons are testing neoliberal extremism. As Huxley (1932) wrote in Brave New World, 'Primroses and landscapes ... have one grave defect: they are gratuitous'!

It is questionable whether secrecy and privacy can really be maintained long in our electronic universe.
The Red Queen hypothesis of co-evolutionary theory (Van Valen 1973, Hamilton 1995) models the arms race needed to maintain demographic stability between predator and prey or host and parasite. It might be used to model the conflicts between merchants and consumers, or between computer security systems and hackers, and would predict constant efforts by both sides to gain advantage. But typically, successful parasites are eventually tamed by their hosts and lose virulence. An analysis of trends in the ways scientific results are communicated as well as initiatives such as the San Francisco Declaration are signs that the level of virulence is being reduced (Moskovkin \& Serkina 2016).

Science has not only been commodified but also infected with deceit. Scientific misconduct is frequently in the news, and editors and referees detect much of it. Misconduct by the gatekeepers of scientific publications has attracted less public attention, but recent revelations concerning the journal Food and Chemical Toxicology (Foucart 2016) detail some corporate lobbying of publishing. Science, like other aspects of culture, is ruthlessly perverted in the service of the market, sometimes with the connivance of editors with elastic views of the truth, willing to ignore or suppress the ethical codes and canons of traditional science. If science provides information which could disturb market interests, then corruption of that science is very likely (Michaels 2008, Oreskes \& Conway 2012).

In this system, space for the motives and aspirations of scientists is reduced, and inspiration is not on the menu. The parameters of acceptable thought are fenced in, as among the twitterati, safe-space freaks, and others who would return to Plato's idola specus. The ideological component has transformed traditional science, by treating it as a manufacturing process with an end product, by rewarding raised productivity, and by harnessing the entire enterprise to its narrow mercantile interests. Freed from the dictates of tradition, new science is forced into more rigid institutional molds, and is explicitly goal-orientated. What we can now witness in some directions is not the modern view of science which emerged with Polanyi's Personal Knowledge (Polanyi 1958) and Kuhn's The Structure of Scientific Revolutions (Kuhn 1962), and with the debate between Lakatos \& Feyerabend (1999), but some eviscerated forms of traditional science.

'Science is dangerous; we have to keep it most carefully chained and muzzled' wrote Huxley (1932). At one time, Soviet ideologists looked unfavorably on Pauling's chemical bonds and Heisenberg's uncer- 
tainty principle, which it was argued were in conflict with Marxism. Are present day ideologists and their ways of managing research also eliminating the mental space within which ideas of equivalent importance might be conceived? The danger Huxley sensed is partially contained. Many of its practitioners have been diverted; they squabble with each other for a share of the tribute, and compete for fatuous symbols of prestige like citation indices, fetishes which elicit the drooling responses of Pavlov's dogs. The algorithms which calculate pecking order recall the hit parades of pop music. Many scientists assure themselves these indices mirror their own achievements without realizing they are being persuaded to behave correctly in conformist communities. These ersatz scientists compete to be promoted and to win some paltry rewards from power. The corollaries are dismissal of the ethical norms of science, and collaboration in corroding the mental space once available to an abandoned calling. Gaming these new norms brings success to the few. Feyerabend (1988) was persuaded that 'anything goes', but even he never imagined how far anything could go.

Ethical obligations are removed and replaced by bureaucratic fetters: 'When people learn no tools of judgement and merely follow their hopes, the seeds of political manipulation are sown.' (Gould 1987, p. 245). The need to accede to market demands is fulfilled by semantic tricks such as assertive sentence titles. The metaphysicians of Tlön in Jorge Luis Borges' Labyrinths (Borges 1962) seek neither truth nor plausibility, but to astonish ('Los metafísicos de Tlön no buscan la verdad ni siquiera la verosimilitud: buscan el asombro.'). Assertive titles 'provide not only the product but the advertisement for it' (Rosner 1990), and are frequently accompanied by insubstantial texts. Besides, anyone who offers certainty is certainly wrong.

Distinctions between science, technology, and business management are increasingly confounded. Knowledge which formerly belonged to a universal commons is now commodified. As other Commons have been in the past, knowledge production is now a commercial enterprise. Productivity is measured by numbers of publications, by patents, and by bibliometric indices. These measures effect a new kind of selection pressure on scientists minds, and the product is recognizably different from that of traditional science (Lynch 2014), and has a distinct aura. It dresses differently too. In our new increasingly online communication channels, the scientific content sometimes seems to take a back seat to the medium, like a 'juicy piece of meat carried by the burglar to distract the watchdog of the mind' (McLuhan 1962).

At the micro-level, this new science offers many opportunities for gaming the system. Smoke and mirrors replace transparency. Statistical analyses are used to obscure understanding rather than explore possibilities, or in attempts to provide a professional gloss. Subtly woven post hoc fallacies creep into funding proposals, wittingly or otherwise, to persuade the unwary. The new values of this new science are reinforced by social conformity. Lapses in the design of protocols provide opportunities for corruption-and for the writing of more and more baroque regulations to counteract it.

One end result is a ranking or hierarchy of scientists, winners and losers. Any solidarity the collective might have had is being crushed, like that of labour unions. It is a curious paradox that individualism among scientists, supposedly a virtue, is being eliminated by bureaucratic planning - a shadow of what Friedrich Hayek, one of the founders of neoliberal economic philosophy, bemoaned. This new paradigm may be making some kinds of scientific activity more efficient or productive, whatever those words might mean in a creative enterprise, but it is simultaneously changing the character of science. Pringle (2013, p. 3281) refers to this 'fouling of the nest', to 'pointless and demeaning squabbles about priority and authorship' and to 'behavior driven by lust for power, money, and fame rather than by any desire to understand nature and (perhaps) improve human wellbeing in the process'. Avant-garde research is hobbled and objectivity is weakened (Fanelli 2012). Has knowledge production been improved? There is no control.

A century ago, Veblen (1918, p. 9) wrote: 'It is always possible, of course, that this pre-eminence of intellectual enterprise in the civilization of the Western peoples is a transient episode; that it may eventually ... perhaps even precipitately, with the next impending turn in the fortunes of this civilization ... again be relegated to a secondary place in the scheme of things and become only an instrumentality in the service of some dominant aim or impulse, such as a vainglorious patriotism, or dynastic politics, or the breeding of a commercial aristocracy'. This analysis has been brought up to date by Bok (2003), Krimsky (2003), Mirowski (2011) and others. If scientists turn away from or shun the traditional ethos without adopting another equally fertile, science itself will languish and degenerate into a mere instrumentality, as Veblen suggested, of gold and iron, money and power. 


\section{LITERATURE CITED}

Agin D (2007) Junk science: how politicians, corporations, and other hucksters betray us. Macmillan Publishers, New York, NY

Anon (2005) The influence of the pharmaceutical industry, Vol 1. United Kingdom House of Commons Health Committee Stationary Office, London

Bauerlein M (2009) The dumbest generation: how the digital age stupefies young Americans and jeopardizes our future. The Penguin Group, New York, NY

Bauwens M (2005) The political economy of peer production. www.ctheory.net/articles.aspx?id=499

Bes-Rastrollo M, Schulze MB, Ruiz-Canela M, MartinezGonzalez MA (2013) Financial conflicts of interest and reporting bias regarding the association between sugarsweetened beverages and weight gain: a systematic review of systematic reviews. PLOS MED 10:e1001578

Biagioli M (2006) Galileo's instruments of credit: telescopes, images, secrecy. University of Chicago Press, Chicago, IL

Bok D (2003) Universities in the market place: the commercialization of higher education. Princeton University Press, Princeton, NJ

Borges JL (1962) Labyrinths. New Directions Publishing, New York, NY

Carey A (1997) Taking the risk out of democracy: corporate propaganda versus freedom and liberty. University of Illinois Press, Urbana, IL

Carson R (1962) Silent spring. Houghton Mifflin, Boston, MA

Collins H, Pinch T (1993) The golem: what everyone should know about science. Cambridge University Press, Cambridge

Dawkins R (1976) The selfish gene. Oxford University Press, Oxford

Dawkins R (1996) The blind watchmaker: why the evidence of evolution reveals a universe without design. WW Norton \& Company, New York, NY

Eco E (1994) How to travel with a salmon and other essays. Harcourt, Orlando, FL

Ernst E (2010) Homeopathy: What does the 'best' evidence tell us? Med J Aust 192:458-460

Fanelli D (2012) Negative results are disappearing from most disciplines and countries. Scientometrics 90:891-904

Feyerabend P (1988) Against method. Outline of an anarchistic theory of knowledge. Verso, London

Foucart S (2016) La discrète influence de Monsanto. Le Monde Science et Techno, 12.07.2016

Fromm E (1964) The heart of man: its genius for good and evil. Harper \& Row, New York, NY

Funtowicz S, Ravetz JR (1993) Science for the post-normal age. Futures 25:739-755

Fuster Morell M (2015) Digital commons and free culture. Editorial Icaria, Barcelona

Gardner M (1952) Fads and fallacies in the name of science. GP Putnam's Sons, New York, NY

Gibbons M, Limoges C, Nowotny H, Schwartzman S, Scott P, Trow M (1994) The new production of knowledge: the dynamics of science and research in contemporary societies. Sage Publications, London

Goldacre B (2008) Bad science. Fourth Estate, London

Gombrich EH (1979) Ideals \& idols. A collection of essays on values and their place in humanity. Phaidon, London

Gould SJ (1981) The mismeasure of man. WW Norton \& Company, New York, NY
Gould SJ (1987) An urchin in the storm: essays about books and ideas. WW Norton \& Company, New York, NY

Gray J (2009) False dawn: the delusions of global capitalism. Granta Books, New York, NY

Gray J (2014) The silence of animals. Penguin Books, London

Gross PR, Levitt N, Lewis MW (1996) The flight from science and reason. New York Academy of Sciences, New York, NY

Guazzo S (1925) The civile conversation of M. Steeven Guazzo. The first three books translated by George Pettie $[\ldots]$ and the fourth by Barth. Young [...] With an introduction by Sir Edward Sullivan. Tudor translations, Series 2, Vols. 7, 8. Constable and Company, London

Hamilton WD (1995) Narrow roads of gene land, Vol 1: evolution of social behaviour. WH Freeman \& Company, New York, NY

Hey T (2006) Foreword. In: C Hine (ed) New infrastructures for knowledge production. Information Science Publishing, London, p vi-vii

Hobbes T (1668) Behemoth, or the long parliament. Simpkin, Marshall, \& Company, London

Hollings K (2008) Welcome to Mars. Politics, pop culture and weird science in 1950s America. North Atlantic Books, Berkeley, CA

Horton R (2004a) The Dawn of McScience. New York Rev Books 51:7-9

Horton R (2004b) MMR science \& fiction: exploring the vaccine crisis. Granta Books, London

Huxley A (1932) Brave new world. Chatto \& Windus, London

Jackson M (2008) Distracted: the erosion of attention and the coming dark age. Prometheus Books, Amherst, NY

Katz J (1997) Birth of a digital nation. Wired 5 (1 April) www. wired.com/1997/04/netizen-3/

Kearns CE, Schmidt LA, Glantz SA (2016) Sugar industry and coronary heart disease research: a historical analysis of internal industry. JAMA Intern Med 176:1680-1685

Klein N (2000) No logo. Vintage Canada, Toronto

Krimsky S (2003) Science in the private interest: Has the lure of profits corrupted biomedical research? Rowman \& Littlefield Publishers, New York, NY

Kuhn TS (1962) The structure of scientific revolutions. University of Chicago Press, Chicago, IL

Kuntz M (2012) The postmodern assault on science. If all truths are equal, who cares what science has to say? EMBO Rep 13:885-889

Lakatos I, Feyerabend P (1999) For and against method. University of Chicago Press, Chicago, IL

Lave R, Mirowski P, Randalls S (2010) Introduction: STS and neoliberal science. Soc Stud Sci 40:659-675

Lessig L (2004) Free culture: how big media uses technology and the law to lock down culture and control creativity. Penguin Press, New York, NY

Loehle C (1990) A guide to increased creativity in research - Inspiration or perspiration? Bioscience 40:123-129

Long PO (2001) Openness, secrecy, authorship: technical arts and the culture of knowledge from antiquity to the renaissance. John Hopkins University Press, London

KLynch K (2014) New managerialism, neoliberalism and ranking. Ethics Sci Environ Polit 13:141-153

Marx K (1846) The German ideology. Cited in: Tucker RC (ed) (1972) The Marx-Engels Reader. WW Norton \& Company, New York, NY

McHenry L (2010) Of sophists and spin-doctors: industrysponsored ghostwriting and the crisis of academic medicine. Mens Sana Monogr 8:129-145 
McLuhan M (1962) Gutenberg galaxy: the making of typographic man. University of Toronto Press, Toronto

Medawar P (1967) The art of the soluble. Oxford University Press, Oxford

Medawar P (1977) Unnatural science. New York Rev Books $24: 13$

Medawar P (1986) Memoirs of a thinking radish. Oxford University Press, Oxford

Merton R (1942) A note on science and democracy. J Legal Polit Sociol 1:115-126

Michaels D (2008) Doubt is their product: how industry's assault on science threatens your health. Oxford University Press, Oxford

Mirowski P (2011) Science-mart: privatizing American science. Harvard University Press, Harvard, MA

Moskovkin VM, Serkina OV (2016) Is sustainable development of scientific systems possible in the neo-liberal agenda? Ethics Sci Environ Polit 16:1-9

Moynihan R, Henry D (2006) The fight against disease mongering: generating knowledge for action. PLOS MED 3: e191

Nentwich M (2003) Cyberscience: research in the age of the internet. Österreichische Akademie der Wissenschaften, Vienna

Nietzsche F (1962) Philosophy in the tragic age of the Greeks. Regnery Publishing, Washington, DC

Nosek BA, Spies JR, Motyl M (2012) Scientific utopia: II. Restructuring incentives and practices to promote truth over publishability. Perspect Psychol Sci 7:615-631

Nowotny H, Scott P, Gibbons M (2003) 'Mode 2' revisited: the new production of knowledge. Minerva 41:179-194

Oreskes N (1999) The rejection of continental drift: theory and method in American earth science. Oxford University Press, Oxford

Oreskes N, Conway EM (2012) Merchants of doubt. Bloomsbury Press, London

Pigliucci M (2002) Denying evolution: creationism, scientism, and the nature of science. Sinauer Associates, Sunderland, MA

Polanyi M (1958) Personal knowledge: towards a post-critical philosophy. University of Chicago Press, Chicago, IL

Polanyi M (1974) Personal knowledge: towards a post-critical philosophy. University of Chicago Press, Chicago, IL

Popper KR (1959) The logic of scientific discovery. Hutchinson \& Company, London

Pringle JR (2013) An enduring enthusiasm for academic science, but with concerns. Mol Biol Cell 24:3281-3284

Proctor RN (1995) Cancer wars: how politics shapes what we know and don't know about cancer. Basic Books, New York, NY

Ramanathan VD (2002) A case of numerophilia. BMJ 325:8

Editorial responsibility: Konstantinos Stergiou,

Thessaloniki, Greece
Ravetz JR (1996) Scientific knowledge and its social problems. Transaction Publishers, London

Resnik DB (2006) Openness versus secrecy in scientific research. Episteme 2:135-147

Ritzer G (1998) The McDonaldization thesis: explorations and extensions. Sage Publications, London

Ritzer G (2011) The McDonaldization of society, 6th edn. Sage Publications, London

Rosner JL (1990) Reflections of science as a product. Nature 345:108

Russo L (1996) La rivoluzione dementicata. Feltrinelli, Milan

Schlain L (1998) The alphabet versus the goddess. The conflict between word and image. Penguin Books, London

Shneiderman B (2008) Science 2.0. Science 319:1349-1350

Shneiderman B (2016) The new ABCs of research: achieving breakthrough collaborations. Oxford University Press, Oxford

Smaldino PE, McElreath R (2016) The natural selection of bad science. R Soc Open Sci 3:160384

Smithson M (1989) Ignorance and uncertainty: emerging paradigms. Springer-Verlag, New York, NY

Sprat T (1667) The history of the Royal Society of London, for the improving of natural knowledge. J Martyn, London

Starr P (1982) The social transformation of American medicine. Basic Books, London

Stocking SH, Holstein LW (2009) Manufacturing doubt: journalists' roles and the construction of ignorance in a scientific controversy. Public Underst Sci 18:23-42

Storetvedt KM (1997) Our evolving planet: earth history in a new perspective. Alma Mater Vorlag, Bergen

Tuchman G (2009) Wannabe U: inside the corporate university. University of Chicago Press, Chicago, IL

Van Valen L (1973) A new evolutionary law. Evol Theory 1: 1-30

Veblen $\mathrm{T}$ (1918) The higher learning in America. BW Huebsch, New York, NY

Waddington $\mathrm{CH}$ (1948) The scientific attitude, 2nd edn. Penguin Books, London

WWatermeyer R, Olssen M (2016) 'Excellence' and exclusion: the individual costs of institutional competitiveness. Minerva 54:201-218

Watson J (1968) The double helix. Weidenfeld \& Nicolson, New York, NY

Wouters PF (1996) Cyberscience. Kennis en Methode 20: $155-186$

Ziman J (1994) Prometheus bound: science in a dynamic steady state. Cambridge University Press, Cambridge

Ziman J (2000) Real science: What it is and what it means. Cambridge University Press, Cambridge

Submitted: February 8, 2017; Accepted: June 18, 2017

Proofs received from author(s): September 21, 2017 